\begin{tabular}{lll} 
KULTURA & $\begin{array}{l}\text { POLSKA A KADEMIA NAUK } \\
\text { KOMITET SOCJOLOGII }\end{array}$ & ISSN 0023-5172 \\
i & $\begin{array}{l}\text { INSTYTUT STUDIÓW POLITYCZNYCH } \\
\text { SPOLECZENSTMO nr } 2\end{array}$ & WIDZIANE W MIEŚCIE \\
\hline
\end{tabular}

BEATA KOWALCZYK

Uniwersytet Warszawski

Paris Panthéon-Sorbonne

\title{
ULICZNI „PRZEDSIĘBIORCY”, CZYLI SPÓR O WIDZIALNOŚĆ W PRZESTRZENI PUBLICZNEJ MIASTA
}

\begin{abstract}
„Najgorzej jest rano, gdy tłum wylewający się z metra natyka się na zasieki z plastikowych worków. To galeria handlowa pod chmurką. W ofercie bluzeczki, sweterki i szale. Do wyboru, do koloru, prosto z wora. [...] Handel naręczny na placyku przed metrem zwanym potocznie patelnią to zjawisko od lat nie do opanowania. Do tego stopnia, że handel coraz bardziej się rozwija: stojące szpalerem handlarki polują na klientów już nie tylko na patelni, lecz także pod hotelem Metropol. Nikt ich nie niepokoi, choć oficjalnie miasto podejmuje działania zmierzające do ukrócenia działalności handlowej wolnej od podatków i pozwoleń. Działają np. patrole straży miejskiej wzmocnione urzędnikami miejskiego biura działalności gospodarczej i zezwoleń, którzy mają uprawnienia do czasowego «aresztowania» towaru. Skutek jest mizerny. - Handlarze są doskonale zorganizowani. Mają czujki. Gdy pojawia się patrol, pakują wory i pryskają. Gdy patrol odchodzi, wracają — przyznaje [...] rzeczniczka straży miejskiej”.
\end{abstract}

Grzegorz Lisicki, Dziki handel $z$ wora...

\section{CZYM JEST HANDEL ULICZNY?}

Spotkać ich można właściwie wszędzie w Warszawie, Paryżu, Wenecji, Pekinie czy w Nowym Jorku. Stoją niepewni swojego losu, w nieustannej gotowości do ucieczki, na ulicach, placach, w przejściach podziemnych i bramach. Najczęściej wybierają ruchliwe, węzłowe punkty na komunikacyjnej mapie miasta — takie, które ze względu na codzienny, intensywny przepływ ludzi gwarantują największe powodzenie tych jednoosobowych "przedsiębiorstw” handlowych.

Adres do korespondencji: b.kowalczyk@is.uw.edu.pl 
Drobni sprzedawcy i sprzedawczynie sznurowadeł, wkładek do butów, parasolek w deszczowe dni, poupychanych w czarne worki na śmieci różnokolorowych niemodnych sweterków, koronkowych bluzeczek, koszulek z długim i krótkim rękawem, spódnic, szali we wzory imitujące wielkie marki modowe funkcjonują na granicy szarej strefy, rynkowych peryferii. Swoją obecnością zakłócają ruch pieszych, przysparzają pracy władzom miasta, zawstydzają jego mieszkańców przed turystami, a jednocześnie utrzymują swoje rodziny realizując prywatny, antysystemowy plan ekonomiczno-gospodarczy, podważając założenia neoliberalnej ideologii niewidzialnej ręki rynku. Wzrost nierówności społecznych oraz eksploatacji taniej siły roboczej na niektórych jednostkach wymusza podjęcie działalności w nieformalnej szarej strefie w celu przetrwania (Fernandez-Kelly 1989).

Zamierzam tu podjąć próbę socjologicznego opisu zjawiska jednoosobowego handlu ulicznego jako formy (nie)widzialnej obecności w przestrzeni publicznej miasta. (Nie)widzialnej w tym sensie, że handlarze, łamiąc przepisy prawa określające ramy publicznej widzialności, balansują na granicy konieczności bycia niewidzialnym dla aparatu władzy, aby uniknąć kary oraz zapewnić sobie możliwość realizowania własnego planu, pomysłu na życie. Nadaje im to status szpiega, tajnego aktywisty, zbuntowanego społecznika i twórcy niewidzialnego miasta. Ryzyko uwidzialnienia w tym wypadku zagraża bezpieczeństwu ich „być”, zarazem jednak widzialność dla potencjalnych nabywców ich towarów jest warunkiem sine qua non powodzenia całego przedsięwzięcia. Problem handlu ulicznego, incydentalnie „zakłócającego” ład publicznej przestrzeni miasta, prowokuje do stawiania pytań między innymi o prawo i zakres, w jakim korzystamy $z$ terenu miejskiego, a także o to, czego symptomem, jakich przemian społecznych, są takie praktyki. Ponadto zachęca do zastanowienia się nad tym, czy bazarowe szczęki, łóżka polowe, które uginają się pod ciężarem rozmaitych dóbr, albo mieniące się kolorami tęczy uliczne suszarki mogą trafić do repozytorium pamięci o polskiej transformacji.

Materiał badawczy stanowiący podstawę rozważań został zgromadzony przeze mnie w roku $2014 \mathrm{w}$ Warszawie, podczas luźno prowadzonych obserwacji handlarzy z okolic placu przy wejściu do stacji metra Centrum, potocznie nazywanego „patelnią”, w przejściu podziemnym przy rondzie Dmowskiego oraz w dzielnicy Saska Kępa. Nieusystematyzowany charakter danych wynika ze wspomnianego już wyżej celu, którym jest raczej próba konceptualizacji opisywanego zjawiska niż jego metodyczne badanie.

Kategorię niewidzialności rozumiem tutaj operacyjnie - za definicją sformułowaną przez Marka Krajewskiego na potrzeby projektu „Niewidzialne miasto” ${ }^{1}$ - jako zespół „codziennych prozaicznych praktyk, które niosą ze sobą

1 „Niewidzialne miasto” to projekt badawczy zainicjowany i zrealizowany przez Zakład Badań Kultury Materialnej i Wizualnej w Instytucie Socjologii UAM. Więcej na ten temat zob. http://www.niewidzialnemiasto.pl 
określone skutki materialne $\mathrm{w}$ postaci zmian $\mathrm{w}$ przestrzeniach wielkich miast - w tym jak są one zorganizowane, jak wyglądają, jakie rodzaje estetyk w nich dominują, czyja kultura może się w nich objawiać w postaci obiektów, sposobów organizacji przestrzeni, wyglądów osób i miejsc" (Krajewski 2012, s. 9). O ile jednak autorzy przywoływanego projektu tropili trwałe efekty powszednich ingerencji mieszkańców w wygląd przestrzeni publicznej, o tyle zmiany w otoczeniu wywoływane obecnością handlarzy ulicznych mają charakter bardziej incydentalny, aczkolwiek ich „pojawianie się” samo w sobie ma pewną wartość emergentną. W tym sensie, że konsekwencją regularnego nawiedzania danego obszaru miasta może być wytworzenie zwyczaju, przyzwyczajenia wśród przechodniów, którzy zapamiętują te punkty na mapie, gdzie można kupić tulipany, a gdzie parasol i gdzie latem ustawia się sprzedawca najtańszych i najlepszych truskawek.

Takie pozycje na mapie miasta stanowią również o jego czytelności (legibility), klarowności w percepcji mieszkańców, tłumaczonej przez Kevina Lyncha w kategoriach „łatwości, z jaką jego [miasta - B.K.] części mogą być rozpoznane i ułożone w spójny wzór" (Lynch 1960, s. 2-3). O czytelności miasta decyduje przede wszystkim jego logicznie uporządkowany, rozpoznawalny układ dróg, w miarę klarowna i logicznie zorganizowana zabudowa architektoniczna. Nie mniej istotna jest jednak obecność Innych w tym sensie, że tworzą oni coś na kształt społecznej mapy miasta opartej na mniej lub bardziej stabilnych relacjach międzyludzkich i interakcjach zachodzących między ludźmi a ich fizycznym otoczeniem. Znajoma pani zostawia mi w reklamówce pod stołem-ladą ulubione jabłka, za które zapłacić mogę dopiero jutro, gdyż w warzywniakach pod gołym niebem nie są honorowane karty płatnicze, o czym ciągle zapominam. W kolejce po te jabłka kwitną sieci sąsiedzkie, dokonuje się wymiana informacji, a gdzieniegdzie nawet powstają zalążki działań społecznych, aktywizujących mieszkańców, zmieniających w konsekwencji przestrzeń miasta. Roch Sulima zauważa, iż zachowania konsumenckie na bazarze i w supermarkecie różni nie tylko swoista „aura”, w jakiej odbywa się wymiana towarów, lecz także wartość i znaczenie samych produktów. Dzieje się tak zwłaszcza wtedy, gdy sprzedawca sam wyhodował oferowane w koszyczku warzywa i owoce, sam wyhaftował obrus itp., co sprawia, że widać w nich jego rękę, „psychologiczno-społeczny profil wytwórcy, dostawcy” (Sulima 2000, s. 149). Każda transakcja jest niepowtarzalna przez skrócenie dystansu między jej uczestnikami dzięki temu, że tematyka rozmowy wybiega daleko poza zwyczajową wymianę grzecznościowych formułek.

Henri Lefebre powiedziałby, że obie strony interakcji: handlarz i nabywca, wytwarzają w ten sposób krótkotrwałą przestrzeń społeczną, w której reprodukowane są stosunki społeczne. Istotnym warunkiem tego procesu jest istnienie „tradycyjnej przestrzeni publicznej, oznaczającej z definicji sferę wolności, gdzie każdy mieszkaniec miasta może czuć się swobodnie [...]. Ulice, place, a także miejskie parki powinny być własnością wszystkich obywateli miasta, 
a zachowania w tej przestrzeni muszą być swobodne, ograniczone jedynie ogólnymi zasadami współżycia społecznego. Oczywiście nie zawsze tak jest, ponieważ administratorzy publicznych przestrzeni wprowadzają różne restrykcje" (Jałowiecki, Szczepański 2006, s. 423-424). Oddolne ingerencje w pejzaż miasta mają tę zaletę, że są odpowiedzią na oczekiwania użytkowników tej przestrzeni i nie wywołują uczucia niepokoju wynikającego z niemożności odnalezienia drogi (horror vacui), zagubienia, będącego czymś więcej aniżeli „geograficzną niepewnością” - „całkowitą katastrofą” (Jałowiecki, Szczepański 2006, s. $4-5)$.

Handel uliczny jest praktykowany na wiele sposobów. W większości przypadków to sprzedaż produktów, czasem usług (czyszczenie butów, ale i prostytucja) lub połączenie obu (Bromley 2000, s. 2). W zależności od czasu i miejsca oferowania towarów i/lub usług stoiskiem handlowym może być torba, poły marynarki, naręcze, wózek, samochód, by można było w razie kontroli policji lub straży miejskiej szybko przenieść działalność. Wraz ze wzrostem przyzwolenia i stopnia legalności punktem sprzedaży stają się suszarki, stoły, łóżka polowe, albo prowizoryczne kioski rozkładane rano i demontowane po zakończeniu dnia handlowego.

Dla niektórych handlarzy ulicznych jest to zajęcie na pełen etat i stanowi strategię przetrwania oraz utrzymania rodziny, dla innych zaś działalność okazjonalna lub dorywcza, w celu podreperowania domowego budżetu. Handlarze uliczni pracują $\mathrm{w}$ pojedynkę, ale i w kooperacji ze wspólnikami, co umożliwia im rozszerzenie skali działalności. Zdarzają się, choć są nieliczne, przypadki udanego rozwoju przedsięwzięcia, na przykład powstaje sklep. Dochody zdecydowanej większości są raczej niskie, porównywalne do średnich zarobków niewykwalifikowanych robotników (Bromley 2000, s. 2-3).

Handel uliczny jest jednym $z$ najstarszych i najbardziej rozpowszechnionych zawodów świata, aczkolwiek nie cieszy się zbytnim zainteresowaniem badaczy (Bromley 2007, s. xv). Europejskie miasta pełne są migrantów oferujących wszelkiego rodzaju towary, od sprzedawanych legalnie na stacjach paryskiego metra produktów spożywczych po kontrabandę (Cross 2007) i podrobione markowe przedmioty, którymi w Wenecji handlują migranci z Afryki. W Polsce walkę o przechodnia-potencjalnego klienta toczą między sobą głównie Polacy i w mniejszym stopniu przybysze zza wschodniej granicy (głównie Ukraińcy). W Turcji handel uliczny to część życia ekonomicznego instytucjonalnie aprobowana ze względu na to, iż stanowi po części antidotum na ogólną obniżkę dochodów, jednak państwo, za pomocą władz samorządowych, stara się utrzymać działalność handlarzy pod jak największym dozorem (Varcin 2007, s. 124). Podobne praktyki objęcia kontrolą instytucjonalną (opodatkowanie wraz z próbą regulacji sposobów zagospodarowania przestrzeni publicznej) stosowano również wobec prowadzonego w większości przez Afroamerykanów bazaru ulicznego w nowojorskim Harlemie (Stoller 1996). 
Współcześnie handlarze uliczni społecznie postrzegani są jako „pasożytujący pośrednicy” (parasite middlemen) (Bromley 2007, s. xv), dysfunkcjonalne jednostki pozbawione politycznego znaczenia, stanowiące tym samym antytezę modernizmu, reprezentowanego przez realne, ale i wirtualne supermarkety oraz galerie handlowe. W różnym czasie i różnych rejonach świata zjawisko to występuje i występowało $z$ różnym nasileniem $w$ zależności od czynników polityczno-ekonomicznych. I wbrew oczekiwaniom, iż handel uliczny zostanie wchłonięty przez kapitalistyczną demokrację, uliczni sprzedawcy nadal mają się dobrze. Jérôme Monnet tłumaczy, że jeśli w niektórych okolicznościach handel uliczny zyskuje aprobatę publiczną, to dzieje się tak dlatego, że ta forma działalności wpasowuje się w postfordowski elastyczny kapitalizm, w którym zgodnie $z$ dominującym ideałem każda jednostka ponosi pełną odpowiedzialność za samą siebie (Monnet 2006, s. 39). Poza tym handlarze uliczni inspirują rozwój parasystemowych struktur sieci współpracy, takich jak kooperatywy handlujące produktami kupowanymi bezpośrednio od rolników (element zachodniej kultury yuppie z lat dziewięćdziesiątych), rozmaitych krótkotrwałych wydarzeń, jak wyprzedaż garażowa, która czasem przyjmuje formę ulicznego handlu na stolikach i łóżkach polowych, nawiązując tym samym niejako do pchlich targów, popularnych wśród „dzieci kwiatów” w latach sześćdziesiątych i siedemdziesiątych XX wieku, czy do popularnych ostatnio w Warszawie weekendowych targów śniadaniowych, gdzie można się zaopatrzyć we wszelkiego rodzaju „zdrową żywność”. Wreszcie handel uliczny legitymizację zyskuje w czasie wydarzeń sportowo-kulturalnych.

Handel uliczny często definiowany jest w kategoriach zjawisk ekonomii nieformalnej (Hart 1973; Castells, Portes 1989) — jako część przednowoczesnego porządku ekonomicznego, która przetrwała jedynie na marginesie społeczeństw kapitalistycznych, choć stymuluje, jak wspomniałam, rozwój podobnych aktywności w małych społecznościach sąsiedzkich i nie tylko. Jednakże takie ramy teoretyczne nie do końca oddają rzeczywistą sytuację. Jeśli za Castellsem i Portesem przyjmiemy, że ekonomia nieformalna to wytwarzanie i/lub dystrybucja dóbr poza systemem regulacji ekonomiczno-prawnych, to okaże się, że nierzadko o nieformalnym wymiarze handlu ulicznego stanowi nie tyle nielegalność samej działalności (handlarze mogą działać $\mathrm{w}$ sposób zgodny z prawem), lecz kontaktów z klientami (Cross, Morales 2007, s. 2).

Badacze podają argumenty za i przeciw popularyzacji handlu ulicznego. Wymowa i znaczenie poszczególnych racji zmieniają się $\mathrm{w}$ zależności od czasu i kontekstu społeczno-kulturowego. „Za” przemawiają następujące cechy tej działalności: przyczynianie się do zwiększenia konkurencji i pobudzenia działalności ekonomicznej w ogóle; jest wyrazem prawa do wolnego decydowania jednostki o wykonywanym zawodzie; zapewnia źródło utrzymania rodzinom jako społeczna safety-net, odciążająca w ten sposób państwo; wpływa na mobilność jednostek w strukturze społecznej i jest ważnym spiritus movens tworzenia się sieci społecznych interakcji, inicjatyw obywatelskich (de Soto 1989) an- 
gażujących różnych aktorów społecznych; stanowi alternatywne źródło towarów dla jednostek o ograniczonych możliwościach realizowania swoich potrzeb konsumpcyjnych w sklepach i galeriach handlowych (Bromley 2000, s. 4-5). Wreszcie handlarze uliczni ożywiają życie na ulicach, zwłaszcza w czasie świąt, festiwali i wydarzeń kulturalnych.

Lista kontrargumentów wydaje się równie długa, choć - jak się wydaje nie mają one wystarczającej mocy dyskredytowania wszystkich „za”. Handel uliczny krytykowany jest przede wszystkim za zwiększanie zatłoczenia ruchliwych już ulic (takie właśnie przyciągają handlarzy ze względu na łatwy dostęp do klienta), utrudnianie komunikacji miejskiej; wzrost zanieczyszczenia; działanie na szkodę państwa (szara strefa) oraz klienta (zaniżanie wagi sprzedawanych produktów, handel towarami podrobionymi, nieświeżymi itd.); łamanie praw pracowniczych (nielegalne zatrudnianie imigrantów czy nieletnich) i wreszcie zakłócanie porządku społecznego, nagabywanie przechodniów, źródło drobnej przestępczości (kradzieże, oszustwa itp.); negatywny wpływ na wizerunek miasta (handel uliczny kojarzy się z ubóstwem i zacofaniem cywilizacyjnym). Dlatego też władze miejskie w większości krajów, w których zjawisko to występuje ze szczególnym nasileniem (Azja, Afryka i kraje Ameryki Łacińskiej), podejmują walkę, jeśli nie o całkowitą likwidację (handel uliczny w pewnych przypadkach ma walory atrakcji turystycznej), to chociaż o uregulowanie tego typu działalności (Bromley 2000, s. 7-10).

\section{„PRZYJAZNE PAŃSTWO”. PRAWNE ASPEKTY (NIE)WIDZIALNOŚCI}

Również w Polsce indywidualna działalność handlowa z różnych względów podlega rozmaitym ograniczeniom administracyjno-prawnym. Można się jednak zastanowić, czy i w jakim stopniu restrykcje te chronią zasady dobrego współżycia społecznego. Komisja Nadzwyczajna „Przyjazne Państwo” do spraw związanych $z$ ograniczaniem biurokracji w listopadzie 2011 roku opracowała projekt zmian mających na celu zlikwidowanie lub zminimalizowanie przez władze lokalne skali nielegalnego handlu $\mathrm{w}$ miejscach do tego nieprzeznaczonych ${ }^{2}$. Osobie łamiącej zakaz grozi kara grzywny (nawet do 5 tys. złotych), a także konfiskata towaru, co według specjalistów w zakresie prawa administracyjnego wymaga uzasadnienia odpowiednią regulacją, a takowa nie istnieje.

Zdaniem osób reprezentujących instytucje państwowe, za uporządkowaniem kwestii nielegalnego handlu ulicznego przemawia fakt, iż zjawisko to pociąga za sobą wiele negatywnych skutków, o których była już mowa, począwszy od wprowadzania do obrotu towarów niewiadomego pochodzenia, poprzez

2 Podstawa prawna: Ustawa $z$ dnia 31 sierpnia 2011 r. o zmianie ustawy - Kodeks wykroczeń, opublikowana 19 października w Dzienniku Ustaw (Dz.U. z 2011 nr 224 poz. 1340). Weszła w życie 19 listopada 2011. 
nieuczciwą konkurencję, łamanie prawa podatkowego i przepisów dotyczących ochrony środowiska, zakłócanie spokoju i ładu publicznego, aż po zagrożenie dla bezpieczeństwa na drogach i ulicach, naruszenie estetyki, porządku i harmonii przestrzeni publicznej czy niekorzystny wpływ na wizerunek danego miasta, a także związane $z$ tym obniżenie wartości rynkowej danego terenu.

Nowe przepisy mające prawnie uregulować ten typ przedsiębiorczości, to znaczy ograniczyć jego swobodny rozwój w przestrzeni publicznej, między innymi poprzez usunięcie kupców do miejsc do tego przeznaczonych, mają chronić uczciwą konkurencję, a przede wszystkim przywrócić porządek na ulicach. Przy czym wydaje się niesłyszalny głos osób będących podmiotem tego prawa, wśród których spotkamy studentów dorabiających sprzedażą wykonanych przez siebie kolczyków, bransoletek itp., a także ludzi starszych sprzedających warzywa i owoce $z$ własnej działki.

Handel uliczny nie jest zjawiskiem typowym jedynie dla naszej części Europy. Wydaje się, że problem dotyczy także miast Europy Zachodniej, zwłaszcza tych przyciągających rokrocznie duże rzesze turystów. Na przykład włoski handel uliczny obfituje w problemy związane $z$ wprowadzaniem do obrotu towarów oznaczonych sfałszowanym znakiem towarowym, naruszających tym samym prawo własności przemysłowej. Problem wejścia w konflikt z prawem jest niewątpliwie wspólny dla polskich i włoskich sprzedawców ulicznych, choć oba przypadki mają nieco inny charakter.

Dlaczego zatem polscy nielegalni handlarze decydują się na prowadzenie działalności niezgodnie z obowiązującymi przepisami. Prawdopodobnie powoduje nimi przede wszystkim niechęć do instytucji i biurokratycznych procedur, kojarzonych z niekończącym się staniem w kolejkach, koniecznością wypełniania niezrozumiałych formularzy, dostarczania rozmaitego rodzaju zaświadczeń, a także długim czasem oczekiwania na decyzję. Istotna jest też chęć uniknięcia podatków. Mandaty dla złapanych na gorącym uczynku handlarzy wypisuje straż miejska i nie mogą one przekroczyć kwoty pięciuset złotych, traktowanej przez „winowajców” jako koszt własny. Sankcje te są zatem nieskuteczne jako mniej dotkliwe niż stosowanie się do zaleceń prawa i płacenie podatków. Bycie niewidzialnym jest optymalne w środowisku prawnym zorganizowanym w sposób niedbały i nieprzyjazny jednostkowym inicjatywom.

\section{DEMORALIZACJA PUBLICZNOŚCI CZY WARUNEK POSTĘPU SPOŁECZNEGO?}

Handel uliczny w Polsce bynajmniej nie jest zjawiskiem nowym. W okresie międzywojennym podlegał ogólnym regulacjom prawnym, a przez ekonomistów uważany był wręcz za warunek rozwoju społecznego. $Z$ badań przeprowadzonych w Warszawie w latach trzydziestych ubiegłego wieku przez ekonomistę Stefana Bauma wynika, iż stale rosnący handel uliczny miał „bezwzględnie poważne znaczenie w gospodarstwie społecznem” (Baum 1930, s. 4). Na najruchliwszych placach i skwerach warszawskich sprzedawano przede wszystkim 
papierosy, gazety, leki, owoce, słodycze kwiaty i warzywa. Latem dodatkowo lody i wodę sodową. Przedmioty handlu powinny być zgodnie z normami prawnymi obowiązującymi na mocy uchwał pisanych przez Radę Miejską. W rzeczywistości każdy handluje, czym tylko może. Ta zasada nie zmieniła się do dziś, gdy pod Halą Mirowską, a także na turystycznym Nowym Świecie spotykamy osoby starsze wyprzedające na kocykach i gazetach znalezione w domu bibeloty, a może i pamiątki całego życia, słowem - wszystko to, co da się spieniężyć i czego szkoda wyrzucić. Niewykluczone, iż wśród handlarzy znajdą się i tacy, którzy kierują się nie motywacją ekonomiczną, lecz potrzebą kontaktów społecznych, bycia z innymi, rozmowy, zainteresowania, wypełnienia społecznej pustki w życiu prywatnym.

Ten rodzaj zajęcia ważny jest, jak wnioskuje Baum (1930, s. 37), dlatego, że zapewnia minimalny dochód, niewystarczający jednak do utrzymania trzy-czteroosobowej rodziny. Podejmują je ci, którzy w innym przypadku nie mogliby znaleźć pracy, na przykład inwalidzi wojenni, osoby niepełnosprawne, starsze, dzieci oraz kobiety. $Z$ kolei ubodzy klienci mają w ten sposób pewien dostęp do towarów, których ze względu na wyższe ceny nie mogliby nabyć w sklepach. Tym samym handel uliczny zwiększa obrót towarów, a ponadto przyczynia się do wzrostu konsumpcji i rozwoju potrzeb.

Wreszcie ten typ aktywności zarobkowej rozwija w ludziach cechy przedsiębiorczości, zaradności i pomysłowości, czego dowodem są historie handlarzy, którym spełniło się marzenie o zamianie drewnianej skrzynki z jabłkami na dobrze prosperujący sklep warzywno-owocowy. Dlatego też, argumentuje Baum (1930, s. 36-37): „dopuszczenie [...] sprzedawców ulicznych do wolnej, nieskrępowanej więzami gospodarczemi, działalności na polu pośredniczenia w obrocie towarów, wskazane jest okolicznością, iż swobodny rozwój sił indywidualnych jest podstawowym warunkiem normalnego postępu społecznego".

Interesujące, że ekonomiczno-społeczna analiza i ocena zjawiska handlu ulicznego sprzed niemal stu lat brzmi niezwykle aktualnie i stwierdzenia te po drobnych zabiegach stylistycznych można by równie dobrze włożyć w usta jednego ze współczesnych neoliberalnych ekonomistów. Osoby uprawiające nielegalny handel uliczny stanowią niejako „niewidzialną rękę”, a raczej protezę ręki wolnego rynku, regulującą $\mathrm{w}$ tym przypadku niedoskonałości organizacji oficjalnego rynku pracy. Podobnie żywo brzmią dziś racje osób krytykujących ówcześnie uliczny geszeft, a dotyczą one między innymi problemu łamania lub naciągania przepisów, braku higieny, demoralizacji wynikającej z tego, że publiczność jest zachęcana „zbyt często do zakupu towarów niepotrzebnych i w złym gatunku", utrudniania ruchu ulicznego czy stwarzania nieuczciwej konkurencji kupcom sklepowym (Baum 1930, s. 34). „Brukowy biznes” tak wtedy, jak i dziś zakłóca ład krajobrazu miejskiego, psuje komfort psychiczny wpływowej grupy mieszkańców, a ponadto funkcjonuje na granicy prawa.

Tego rodzaju manifestacje indywidualnej przedsiębiorczości nie były zapomniane w czasach PRL-u, funkcjonowały w postaci targowisk, bazarów odpu- 
stowych i jarmarków wiejskich. Można zatem mówić o pewnej ciągłości fenomenu handlu ulicznego, niemal zawsze pełniącego funkcję substytutu maskującego luki niedoborów w gospodarce albo metonimii potępianej w tamtym okresie konsumpcji. Analizując zjawisko SHM (super-hiper-megamarketów) Roch Sulima zwraca uwagę na to, iż „codzienna rzeczywistość jako dom, do tego jeszcze dom w permanentnej budowie, wyraża ideę community economy (gospodarkę wspólnoty), z którą łączy się przekonanie o ograniczonych zasobach dóbr i prowadzi do [...] potępienia konsumpcji, albowiem jeśli jeden z członków wspólnoty konsumuje więcej, zabraknie innemu" (Sulima 2000, s. 133).

Pojawienie się w latach dziewięćdziesiątych nowych przybytków handlu, o funkcjach dalece wykraczających poza oczekiwania ówczesnych konsumentów, nie zniszczyło bazarowej formy wymiany handlowej, lecz paradoksalnie, jak podkreśla Sulima (2000, s. 148), przyczyniło się do jej modernizacji, która „wydobyła ich potencjał, zmieniła spojrzenie na usługi w skali "przydomowej» czy osiedlowej”. Ten typ działalności wciąż wymaga pogłębionych studiów antropologicznych, ponieważ dotyczy ważkiego zjawiska „naszej formy ekonomii kulturowej". Warto zauważyć w tym miejscu, że kształtująca się od lat dziewięćdziesiątych łóżkowo-szczękowa odmiana jarmarcznych zakupów służyła, oprócz zapełniania nisz konsumenckich na raczkującym rynku kapitalistycznym, również akumulacji kapitału i dała początek pierwszym fortunom.

Podobne obserwacje prowadzili socjologowie rosyjscy opisujący zmiany na ulicach Petersburga po upadku ZSRR. „Na początku lat dziewięćdziesiątych wszyscy w Petersburgu coś sprzedawali: żywność, różne artykuły, członek Akademii Nauk sprzedający warzywa, filolog handlujący pościelą na zaimprowizowanym stoisku czy inżynier oferujący na ulicy ręcznie robione wełniane skarpety. W okolicach stacji metra studenci handlowali kupionym $\mathrm{w}$ sklepie tanim piwem, zarabiając na tym niewielką prowizję, a pracownicy fabryk, których często wynagradzano wytwarzanymi produktami zamiast pieniędzmi (powszechna praktyka ze względu na generalne braki w gotówce), sprzedawali czajniczki do kawy, talerze, łyżki, również buty i ubrania, jeśli mieli wystarczająco dużo szczęścia i pracowali w odpowiednich zakładach" (Pachenkov, Berman 2007, s. 201-223). W drugiej połowie lat dziewięćdziesiątych sprzedaż uliczna została $\mathrm{w}$ jakimś sensie zinstytucjonalizowana (uporządkowana na targowiskach handlowych itp.) i poddana większej kontroli instytucjonalnej, także ze względu na powstanie gangów wyłudzających opłaty za rzekomą ochronę sprzedawców, tzw. krysza (dach) (Pachenkov, Berman 2007, s. 223).

Istotnym punktem wspólnym $\mathrm{w}$ charakterystyce zjawiska $\mathrm{w}$ okresie międzywojnia w PRL-u i dziś, na początku XXI wieku, jest to, że daje ono namacalne świadectwo niedawno przebytej choroby czy nieudolnie przeprowadzonej operacji. Operacją nazywam proces transformacji reorganizującej rzeczywistość społeczną według zasad neoliberalnej ekonomii z pominięciem interesu ogółu ludności. Handlarze uliczni są znakiem przejścia od gospodarki socjalistycznej do kapitalistycznej i jako symboliczny obraz polskiego protokapitalizmu lat 
osiemdziesiątych i dziewięćdziesiątych ubiegłego wieku przypominają o błędach popełnionych przez ówczesne klasy rządzące i nie pozwalają odciąć historii pięćdziesięciu lat socjalizmu grubą kreską szminki reklam, kolorowych fasad sklepów, domów, biurowców w zmieniającej się postnowoczesnej rzeczywistości. Ich obecność w centrum Warszawy świadczy z jednej strony o ciągłości historycznej, a z drugiej jest symptomem niedomagań systemowo-instytucjonalnych dzisiejszego państwa. Jakie to niedomagania?

\section{„CHICHOT” HANDLARZA ULICZNEGO}

Niektórzy politolodzy, ekonomiści czy socjolodzy zajmujący się przemianami ustrojowymi w krajach postkomunistycznych, jak Iwan Krastew czy David Ost (2010) ${ }^{3}$, a w Polsce między innymi Witold Morawski czy Jacek Kochanowicz, wskazują na to, że beneficjentami strukturalnej transformacji gospodarki są przede wszystkim elity. To znaczy członkowie klasy politycznej, osoby projektujące transformację oraz te, które miały dostęp do informacji niezbędnych w rozkręcaniu własnych przedsiębiorstw albo posiadały i umiały wykorzystać kapitał kulturowo-społeczny (wiedza, języki obce, znajomości). Oczywiście nie należy zapominać o „klasie nowobogackich”, między innymi dawnych „cinkciarzy”, „badylarzy”, czyli osób, które zbudowały swoje majątki w szarej strefie, wykorzystując uwarunkowania gospodarki niedoboru, to znaczy wypełniając lukę między zapotrzebowaniem na pewne towary (walutę obcą, ale także produkty pierwszej potrzeby, na przykład artykuły rolne, niedostępne na rynku oficjalnym) a ich podażą.

Według zasad neoliberalnej ekonomii opartej na wierze w amerykański sen o merytokratycznie dzielonym torcie sukcesu i powodzenia w życiu jednostki to ona sama odpowiada za swój los i ewentualne porażki (kwestia blaming the victim; Ryan 1971). Kiedy jednak właściciel tęczowej suszarki ze sznurowadłami albo pani $z$ naręczem bluzeczek próbują działać w myśl własnej interpretacji reguł gry obowiązujących w gospodarce kapitalistycznej, wówczas wpadają w sieci praw sterujących niewidzialną ręką rynku, krępujących tym samym ich poczynania.

Nie chodzi tu o formułowanie bezkrytycznej linii obrony ulicznych handlarzy czy o popieranie nielegalnego działania na szkodę państwa (niepłacenie podatków, będących między innymi źródłem finansowania infrastruktury, z której korzystają również handlarze), czy też o krytykę instytucji państwowych. Chodzi raczej o zwrócenie uwagi na oderwanie sfery politycznej, rozumianej tu przede wszystkim w kategoriach stanowienia prawa przez urzędników państwowych, od rzeczywistości społecznej, będącej niejako kontynuacją strategii funkcjonowania państwa komunistycznego, ale i oktrojowanej przez specja-

${ }^{3} \mathrm{~W}$ tym artykule Ost za Krastewem podkreśla, że wyobcowanie elit nie jest zjawiskiem wyłącznie postkomunistycznym, powołując się na analizy Christophera Lascha z książki Bunt elit. 
listów oraz urzędników państwowych okresu transformacji. Inicjatorzy przemian wyznają po latach, że nie starczyło im czasu na konstruktywną refleksję nad losem mieszkańców likwidowanych PGR-ów czy nad konsekwencjami niekontrolowanej prywatyzacji przedsiębiorstw państwowych. Ofiary przeobrażeń strukturalnych otrzymały w zamian obietnicę wolności do wyrażania własnego zdania, do podejmowania aktywności ekonomicznej, która wiązała się jednak z tym, że państwo przerzuciło na nich odpowiedzialność za własną pozycję na rynku pracy. Wolność już wkrótce okazała się mitem, a władza państwowa posługując się narzędziami rozrastającej się biurokracji stopniowo zwiększyła kontrolę nad indywidualnymi poczynaniami obywateli, i zepchnęła „radzących sobie" handlarzy do szarej strefy.

Za sprawą kupców oferujących przechodniom warszawskich ulic, placów i skwerów różnorakie towary usłyszeliśmy chichot liberalnej transformacji. Ów chichot ma dwojaki wydźwięk. Z jednej strony postać handlarza ulicznego jest ironiczną deformacją zasady i efektów działania niewidzialnej ręki neoliberalnego rynku, $z$ drugiej jednak słychać w nim rozżalenie i gniew ofiar tej ideologii, pozostających $z$ instytucjami państwa w konflikcie o „być” w tym systemie gospodarczym. Tymczasem władza publiczna za pomocą regulacji prawnych, medialnie dystrybuowanych racjonalizacji swoich działań i wreszcie przy użyciu siły fizycznej straży publicznej dąży do usunięcia handlarzy ulicznych z przestrzeni miejskiej w ramach jej rewitalizacji, reorganizacji, rewaloryzacji i czyszczenia, spychając niewygodne „obrazy” w najlepszym wypadku na obrzeża stolicy, jak w przypadku likwidacji hal KDT (Kupieckich Domów Towarowych) sprzed Pałacu Kultury w 2009 roku.

\section{KOMU PRZESZKADZA „TECCZA”?}

Dlaczego owe obrazy są niewygodne? Najprawdopodobniej z tego powodu, że przypominają o trudnych początkach polskiego kapitalizmu, rodzącego się $\mathrm{w}$ przejściach podziemnych, na kartonach, składanych łóżkach polowych, nazywanych popularnie „szczękami”, zrównującego wszystkie grupy społeczne niezależnie od posiadanego kapitału społeczno-kulturowego: lekarz obok prawnika i szeregowego pracownika sprywatyzowanej, a następnie zamkniętej fabryki. Jednak tym pierwszym, to znaczy osobom $z$ wyższymi zasobami, udało się wkrótce awansować $\mathrm{z}$ ulicy na stanowiska $\mathrm{w}$ prywatnych przedsiębiorstwach, reszta $\mathrm{w}$ najlepszym przypadku dorobiła się stoiska w halach czy na bazarach. To ci pierwsi, tak zwani wygrani transformacji, są autorami opresyjno-represyjnego systemu prawnego, będącego narzędziem $\mathrm{w}$ walce o przejęcie kontroli nad jak największą pulą zasobów, dóbr na rynku i jednoczesną próbą jego regulacji. Ta posttransformacyjna wspólnota ekonomiczno-społeczna jest efemerycznym rezultatem nagłych przekształceń polityczno-gospodarczych, chwilowej anomii cechującej okres przejścia z jednego porządku do drugiego i ulega rozpadowi wraz ze stopniowym kształtowaniem się i osadzaniem 
w rzeczywistości nowego ładu politycznego. Stare ustępuje miejsca nowemu, wypierane jest ze świadomości albo ulega przekształceniom według nowych zasad organizacji pamięci społecznej.

Ów proces wypierania, przepisywania na nowo niewygodnych fragmentów historii może się odbywać za pomocą opisywanej przez Aleidę Assmann (2009, s. 333-349) strategii wyłączania. Pamięć - jako podstawa autorefleksyjności, tworzenia własnego wizerunku, własnej tożsamości — dopasowywana jest do aktualnej sytuacji, jej warunków i potrzeb osób, które się w niej znajdują. „Zarówno dla spostrzeżeń w teraźniejszości, jak i później dla wspomnień społeczeństwo określa ramy odniesienia i wzorce interpretacji, które decydują o tym, co i jak z (przeszłości) skupia na sobie uwagę i zostaje wyartykułowane. Ta zmiana ram pamięci zależy od wewnętrznych i zewnętrznych czynników" - argumentuje autorka (Assmann 2009, s. 341-342). Jako jeden $z$ istotnych czynników inicjujących proces zapominania w kontekście wewnątrzpolitycznym Assmann podaje przemianę systemu politycznego. Warto tu przypomnieć, iż władza nad pamięcią to władza nad tym, co istnieje. W tym kontekście wymazywanie $z$ repozytorium pamięci ulicznych handlarzy można odczytać jako próbę zrzucenia zasłony milczenia na metody oraz efekty przeprowadzenia transformacji ustrojowej w Polsce od strony instytucjonalnej.

Z perspektywy indywidualnej zaś zapominaniu sprzyja, jak się wydaje, chęć wyparcia niechlubnego epizodu $\mathrm{w}$ życiorysie, gdy panujące $\mathrm{w}$ okresie transformacji warunki ekonomiczne ograniczały wachlarz możliwości zarobkowania do takich prymitywnych form wymiany handlowej jak sprzedaż uliczna. Obecnie podłożem tego uczucia staje się rosnąca liczba turystów albo city users, którzy odwiedzają stolicę, by zweryfikować albo potwierdzić stereotypowe wyobrażenie o robotniczo-wiejskich zacofanych społeczeństwach ubogich sąsiadów $z$ krajów Europy Środkowo-Wschodniej, a przed którymi należałoby ukryć „niedorozwój”, „opóźnienie” w rozwoju społeczno-ekonomicznym, aby pozbyć się obraźliwej etykietki. Albowiem w jet era, czyli w czasach zwiększonej mobilności ludzi, jak analizuje Guido Marinotti (1996), modyfikacjom ulega struktura społeczna miast na świecie: znacznie wzrasta liczba wspomnianych wyżej city users (użytkowników miasta) oraz commuters (dojeżdżających), tak iż nierzadko przewyższają oni liczebnością populację mieszkańców, czego przykładem może być Wenecja.

Białe plamy w biografii jednostki, białe plamy na mapie społecznej miasta, powstające za sprawą (nie)obecności handlarzy, ustępujących przed strażą miejską dziś, aby powrócić na chwilę jutro, ewentualnie odtworzyć swoje przedsiębiorstwo na innej ulicy, $\mathrm{w}$ innym przejściu podziemnym, zagospodarowywane są zgodnie $z$ założeniami praktyk urbanistycznych podporządkowanych strategii rynkowej polityki segregacji (de Certeau, Giard, Mayol 2011, s. 123-133), nowego „grodzenia” tego, co powinno stanowić własność publiczną. Prawo do miejsc tranzytowych, atrakcyjnych z punktu widzenia rozmaitych graczy na rynku, uzurpują sobie agenci generujący zysk, legitymizacji 
swego utylitarystycznego postępowania szukając w celu, jakim jest maksymalizacja dobra społeczności miejskiej. Zawłaszczaniu obszarów miasta towarzyszy czyszczenie jego przestrzeni z elementów psujących wizerunek, a tym samym obniżających jej wartość rynkową. Władze miejskie i prywatne przedsiębiorstwa wypychają wszelkie personae non gratae, jak kupcy uliczni, z centrum miasta na jego obrzeża, w niewidzialną przestrzeń alkowy. Tam jednak gdzieniegdzie zawiązują się wspólnoty sąsiedzkie, ruchy lokatorskie, inicjatywy szalonych społeczników, ukierunkowane na rozwiązywanie bieżących problemów, a w dłuższej perspektywie także na ochronę przestrzeni sąsiedzkiej przed obcy$\mathrm{mi}$ - potencjalnym zagrożeniem dla sąsiedzkiego porządku. Procesy te stanowią przeciwwagę dla polityki administracyjnej, a tym samym komplikują obraz rzeczywistości, pozbawiając go dychotomicznego podziału na widzialnych/widzianych i (nie)widzialnych/(nie)widzianych.

Analogię tej sytuacji znajdziemy w dziewiętnastowiecznych przemianach urbanistycznych europejskich stolic, Londynu i Paryża, poddanych „procesowi homogenizacji na bazie ekonomicznej” (Sennett 2009, s. 226). Rozwój przemysłu $z$ jednej strony i reformy urbanistów, jak słynna reforma Haussmanna, $z$ drugiej strony sprawiły, że w pewnym momencie społeczne mapy tych stolic zostały przeorganizowane ze względu na klasową segregację. Doświadczanie miasta, rozumiane jako poznanie co najmniej kilku jego dzielnic związane z możliwością poruszania się po jego obszarze, stało się dostępne jedynie warstwom uprzywilejowanym ze względu na stan posiadania, ilość czasu wolnego i możliwość korzystania $z$ atrakcji, jakie ono oferowało. Kosmopolityzm klas niższych zaś, rozumiany w kategoriach zetknięcia się z miejską różnorodnością, był związany przede wszystkim z konsumpcją - członkowie uboższych warstw społecznych, podobnie jak dziś, przemierzali jego dzielnice w poszukiwaniu tanich towarów (Sennett 2009, s. 227).

\section{„BUNT” NA ULICY}

Współczesne bazary, targowiska i wreszcie indywidualny handel naręczny, jak się wydaje, jest odpowiedzią na tamten kosmopolityzm i stanowi przeciwwagę dla luksusowej konsumpcji. Dlatego też szuka dla siebie miejsc przy głównych arteriach miasta, tuż za rogiem ekskluzywnych - czyli wykluczających $z$ udziału jakąś grupę osób - sklepów, które oferują drogie symbole statusu społecznego. Tak oto ten rodzaj działalności pełni aktywną, choć zapewne nieurefleksyjnioną rolę $\mathrm{w}$ walce $z$ wykluczeniem i segregacją miasta, $z$ nieformalnym, lecz w gruncie rzeczy usankcjonowanym polityką urbanistyczną odmawianiem doń prawa niektórym grupom jego mieszkańców, spychaniem ich w sferę niewidzialności. W odpowiedzi na te praktyki „niewidzialni” organizują sobie ruchomą alternatywę dla takiej rzeczywistości, jaką chcą widzieć władze oraz przedsiębiorcy monitorujący krzywą wartości ekonomicznej przestrzeni miejskiej, w której lokują swe obecne i przyszłe inwestycje. 
Taką (nie)widzialną alternatywą dla widzialnej rzeczywistości jest ruchoma „galeria pod gołym niebem”, odtwarzana codziennie mniej więcej w tym samym miejscu. To w zasadzie antygaleria, efemeryda, pojawiająca się i znikająca w ciągu kilku chwil, o charakterze festiwalu czy odpustu, wytwarzająca jarmarczną wspólnotę kupców i sprzedawców, opartą na epizodycznych kontaktach, nietrwałych relacjach. Handel uliczny antygalerią jest w tym sensie, iż po pierwsze, nie ma stale wyznaczonego miejsca, budynku, gdzie kupcy mogliby oferować swoje towary w atrakcyjnej oprawie. Po drugie, dlatego że forma zakupów ze sklepów-toreb, łóżek polowych, suszarek pozbawiona jest aury celebry, wybierania, mierzenia, dopasowywania, oglądania, flânerie, spacerowania między półkami, witrynami. Tu wszystko dokonuje się $\mathrm{W}$ pośpiechu, w strachu sprzedającego przed nalotami straży miejskiej oraz z zażenowaniem i poczuciem wstydu kupującego, które często wynikają $z$ sytuacji materialnej, pozwalającej tylko na taki antykonsumpcjonistyczny sposób stwarzania poprzez konsumpcję własnego wizerunku, społecznej tożsamości. O niewidzialności zaś stanowi czynnik polityczny: bezsilność handlarzy ulicznych wobec formalnej działalności handlowej, reprezentowanej przez sklepy i centra handlowe, które odmawiają im prawa do istnienia (Cross 1998).

"Galerie" na wolnym powietrzu pojawiają się dziś również niejako na zgliszczach małych osiedlowych sklepów, które nie wytrzymały konkurencji z centrami handlowymi, w walce $z$ agresywną polityką ekspansji w przestrzeni miejskiej tych ostatnich. Tkanka miejska traci w ten sposób swój polifoniczny charakter, a polityka centrów handlowych oraz supermarketów staje się nowym narzędziem segregacji według zawartości koszyka z zakupami (Jałowiecki, Szczepański 2006, s. 424).

Podczas gdy shopping malls, skądinąd same nieodporne na przekształcenia, pogłębiają podziały społeczne, dzieląc ludzi na swoich potencjalnych klientów oraz tych, którzy ze względu na wiek i zasobność portfela nigdy nimi nie będą, jednoosobowe stoiska handlowe pojawiają się w na nowo uporządkowanej przestrzeni $\mathrm{w}$ formie incydentu, niby kwestionującego krystalizujące się układy, a jednocześnie rekonstruującego zróżnicowanie społeczne. Istnienie jednoosobowych galerii uwarunkowane jest bowiem przede wszystkim ekonomicznie, a ich klientami stają się głównie, jak wspomniałam, osoby z uboższych warstw społecznych, którym odmawia się prawa do wytwarzania i posiadania własnych wzorów konsumpcji. Na marginesie tylko dodam, że skądinąd zakupy u ulicznych handlarzy, w szczególności tych sprzedających warzywa i owoce, wpisują się również w tak zwany trend „spowalniania” (slow food w przeciwieństwie do fast food), kontestujący współczesne życie w biegu, pogoń za karierą, popularnością $\mathrm{W}$ mediach społecznościowych, sukcesem itd. W tej perspektywie ich postrzeganie społeczne ulega modyfikacji. Z drobnych pseudoprzedsiębiorców funkcjonujących na granicy prawa stają się częścią pewnego stylu życia, modnego także wśród osób zamożnych. 
Mimo to samo zjawisko handlu ulicznego - i kontrowersje wokół niego — jest $\mathrm{w}$ istocie przywracaniem przestrzeni publicznej charakteru dialogiczno-agonicznego, zmuszając otoczenie do odpowiedzi, wszczęcia działań mających na celu przeredagowanie porządku społecznego. Niestety, reakcja władz nakierowana jest głównie na uciszenie intruzów i wypchnięcie ich ze sfery widzialności. Niewykluczone jednak, że cała ta awantura o szczęki, tęczowe suszarki, sweterki w worach na śmieci, tulipany czy naręcza czosnku wywoła szerszą dyskusję dotyczącą kluczowych kwestii związanych z prawem do miasta, jego geografią społeczną i polityką ekonomiczno-historyczną sprzedawania miasta $\mathrm{w}$ postaci bogato ilustrowanego albumu $\mathrm{z}$ atrakcjami turystycznymi. Współczesne przekupki zaś i sprzedawcy parasoli mogą łatwo stać się częścią miejskiego folkloru.

\section{TO NIE KONIEC TEJ HISTORII}

Tęczy nie można łatwo wymazać, ani zapomnieć. Najpierw należałoby wystosować żądanie do paryskiego Centre Pompidou o usunięcie jednego z dzieł ze stałej ekspozycji kolekcji sztuki współczesnej. A chodzi tu o Tęczę Pawła Althamera z 2004 roku. Pod nazwą tą kryje się instalacja sporządzona z suszarki do bielizny gęsto obwieszonej różnobarwnymi sznurowadłami, obłożonej z góry wkładkami do butów. Na stronie centrum znajdziemy taką oto eksplikację kuratorską dzieła polskiego artysty:

„Tęcza jest czymś w rodzaju wózka na kółkach, suszarką do bielizny, oderwaną niejako od swojej oryginalnej funkcji, tak jak to często widać na warszawskich bazarach. Przeznaczona do ekspozycji sznurowadeł oraz wkładek do butów, ta przypadkowa konstrukcja, kojarzona $z$ biedą oraz nomadyzmem, łączy w sobie kulturę Europy Wschodniej oraz amerykański sen o wachlarzu możliwości, jakie niesie każdy dzień, wielobarwnym niczym sportowe buty idoli, oznaka wyróżnienia, o którą walczą między sobą nastolatki" 4 .

Ta materialna reprezentacja istotnego aspektu polskiej transformacji jest obrazem wypieranym wprawdzie z polskiej pamięci społecznej za pomocą wyżej opisanych zabiegów, lecz trafia do rezerwuaru historii europejskiej, niesłusznie zresztą i w sposób uproszczony podsumowując drogę modernizacji we wszystkich krajach Europy Wschodniej. Ten obraz oddzielony od społecznego kontekstu zarówno zniewala, operując stereotypicznym wyobrażeniem o tej części Europy, ale i wyzwala, gdyż mimo wszystko oddaje głos temu, co (nie)widzialne, co spychane w zapomnienie. Polityczny wymiar artystycznej wypowiedzi Althamera zasadza się na sile jego dzieła „ustanawiającej bycie razem [être-en-commun]" (Rancière 2007, s. 21) - symboliczne przywrócenie

${ }^{4}$ Christine Macel, Extrait du catalogue Collection art contemporain - La collection du Centre Pompidou, Musée national d'art moderne, sous la direction de Sophie Duplaix, Centre Pompidou, Paris 2007 (https://www.centrepompidou.fr/c pv/resource/cgzoRR/rEnrXy4). 
wspólnocie niewidzialnych jej członków, którzy uosabiają niewygodne wspomnienia o trudnej transformacji. Warto przypomnieć dalej za francuskim filozofem, że obraz artystyczny ma tę przewagę nad polityczną propagandą, iż za pomocą metafory poszerza horyzont myślenia o danym problemie (Rancière 2007, s. 21). Metafora wyrywa fakty z rzeczywistości, umiejscawiając je w przestrzeni symbolicznej, w szerszym kontekście wiedzy historyczno-kulturowej, i łagodzi tym samym ich polityczną drażliwość. Aby to jednak było możliwe, aby nie dopuścić do krzywdzących uproszczeń w postrzeganiu i interpretacji Althamerowskiej Tęczy z jednej strony oraz zachować ciągłość historyczną, uspójnić narrację o społecznej tożsamości z drugiej, należy wywołać temat zjawiska handlu ulicznego na wokandę, przepracować jego znaczenie oraz funkcję społeczno-historyczną.

\section{BIBLIOGRAFIA}

Assmann Aleida, 2009, Pięć strategii wypierania ze świadomości, w: Magdalena Saryusz-Wolska (red.), Pamięć zbiorowa i kulturowa. Wspótczesna perspektywa niemiecka, Univesitas, Kraków.

Baum Stefan, 1930, Handel uliczny w Warszawie, nakładem Wyższej Szkoły Handlowej w Warszawie, Warszawa.

Bromley Ray, 2000, Street Vending and Public Policy: A Global Review, „International Journal of Sociology and Social Policy", t. 20, nr 1/2, s. 1-28.

Bromley Ray, 2007, Foreward, w: John C. Cross, Alfonso Morales (red.), Street Entrepreneurs: People, Place, and Politics in Local and Global Perspective, Routledge, London-New York.

Castells Manuel, Portes Alejandro, 1989, World Underneath: The Origins, Dynamics and Effects of the Informal Economy, w: Manuel Castells, Alejandro Portes, Lauren A. Benton (red), The Informal Economy: Studies in Advanced and Less Developed Countries, John Hopkins University Press, Baltimore.

Certeau Michel de, Giard Luce, Mayol Pierre, 2011, Wynaleźć codzienność, t. 2: Mieszkać, gotować, tłum. Katarzyna Thiel-Jańczuk, Wydawnictwo UJ, Kraków.

Cross John C., 1998, Informal Politics: Street Vendors and the State in Mexico City, Stanford University Press, Stanford.

Cross John C., 2007, Pirates on the high streets: the street as a site of local resistance to globalization, w: John C. Cross, Alfonso Morales (red.), Street Entrepreneurs: People, Place, and Politics in Local and Global Perspective, Routledge, London-New York.

Cross John C., Morales Alfonso, 2007, Introduction: Locating Street Markets in the Modern/Postmodern World, w: John C. Cross, Alfonso Morales (red.), Street Entrepreneurs: People, Place, and Politics in Local and Global Perspective, Routledge, London-New York.

De Soto Hernando, 1989, The Other Path: The Invisible Revolution in the Third World, Harper and Row, New York.

Fernandez-Kelly Garcia, 1989, Informalization at the Core: Hispanic Women, Homework, and the Advanced Capitalist State, w: Alejandro Portes, Manuel Castells, Lauren A. Benton (red), The Informal Economy: Studies in Advanced and Less Developed Countries, John Hopkins University Press, Baltimore.

Hart Keith, 1973, Informal Income Opportunities and Urban Employment in Ghana, „The Journal of Modern African Studies", t. 11, nr 1, s. 61-89.

Jałowiecki Bohdan, Szczepański Marek, 2006, Miasto i przestrzeń w perspektywie socjologicznej, Scholar, Warszawa. 
Krajewski Marek, 2012, Niewidzialne miasto - uspołeczniajacca moc fotografii, w: Marek Krajewski (red.), Niewidzialne miasto, Fundacja Bęc Zmiana, Warszawa.

Król Marcin, 2014, Byliśmy głupi, wywiad, „Gazeta Wyborcza”, 7 lutego.

Lisicki Grzegorz, 2012, Dziki handel $z$ wora w ścistym centrum miasta. Bezkarny?, 2 maja (http:// warszawa.gazeta.pl/warszawa/1,34889,11649826,Dziki_handel_z_wora_w_scislym_centrum_ miasta__Bezkarny_.html).

Lynch Kevin, 1960, The Image of the City, The MIT Press, Cambridge Mass.

Martinotti Guido, [1996], The New Social Morphology of Cities, Management of Social Transformations - MOST, Discussion Paper Series, $\mathrm{nr} 16$ (http://www.unesco.org/most/martinot.htm).

Monnet Jérôme, 2006, Le commerce de rue, ambulant ou informel et ses rapports avec la métropolisation : une ébauche de modélisation, „Autrepart”, nr 39.

Ost David, 2010, Dlaczego polskie elity nie są zainteresowane reszta społeczeństwa, tłum. Tomasz Bieroń, „Newsweek Polska”, nr 2.

Pachenkov Oleg, Danielle Berman, 2007, Spaces of Conflict and Camaraderie: The Contradictory Logics of a Postsocialist Flea Market, w: John C. Cross, Alfonso Morales (red.), Street Entrepreneurs: People, Place, and Politics in Local and Global Perspective, Routledge, London-New York.

Rancière Jacques, 2007, Estetyka jako polityka, tłum. Julian Kutyła, Paweł Mościcki, Krytyka Polityczna, Warszawa.

Ryan William, 1971, Blaming the Victim, Random House, New York.

Sennett Richard, 2009, Upadek człowieka publicznego, tłum. Hanna Jankowska, Muza, Warszawa.

Stoller Paul, 1996, Spaces, Places, and Fields: The Politics of West African Trading in New York City's Informal Economy, „American Anthropologist”, t. 98, nr 4, s. 776-788.

Sulima Roch, 2000, Antropologia codzienności, Wydawnictwo UJ, Kraków.

Varcin Recep, 2007, The Conflict Between Street Vendors and Local Authorities: The Case of Market Traders in Ankara Turkey, w: John C. Cross, Alfonso Morales (red.), Street Entrepreneurs: People, Place, and Politics in Local and Global Perspective, Routledge, London-New York.

\section{STREET 'ENTREPRENEURS', OR THE DISPUTE OVER VISIBILITY IN THE URBAN PUBLIC SPACE}

\section{Summary}

This text is an attempt at a sociological description of the phenomenon of street trading as a form of (in)visible presence in the public space of the city. Street traders are (in)visible in the sense that, in breaking the legal regulations setting the frame for public visibility, they must be invisible to the apparatus of power in order to avoid fines and ensure their ability to achieve their aims, their livelihoods. On the one hand, street traders balance on the edge of the law, transgressing the public order, and on the other hand, they are active creators of its (in)visible portion, metaphorically speakingprotesters against the established socio-cultural structures but in reality people seeking the means to survive.

\section{Key words / słowa kluczowe}

street trading / handel uliczny; public space / przestrzeń publiczna; urban space / przestrzeń miasta; social invisibility / społeczna niewidzialność 